\title{
Inhibition of Cell Cycle Progression through Specific Phase by Pancratistatin Derivatives
}

\author{
Motoh Mutsuga, Keisuke Kojima, Miwako Yamashita, Takamasa Ohno, Yukio Oginara, and \\ Makoto INOUE* \\ Laboratory of Pharmacognosy, Graduate School of Pharmaceutical Sciences, Nagoya City University, 3-1 Tanabe-dori, \\ Mizuho-ku, Nagoya 467-8603, Japan. $\quad$ Received October 11, 2001; accepted October 29, 2001
}

\begin{abstract}
Pancratistatin derivatives, 1-O-(3-hydroxybutyryl)pancratistatin (HBP) and 1-O-(3-O- $\beta$-D-glucopyranosylbutyryl)pancratistatin (GBP), showed strong cytostatic activity against rat embryo fibroblast $3 Y 1$ at concentrations less than $1 \mu_{\mathrm{M}}$. When the effect on cell cycle progression was examined in $3 Y 1$ fibroblasts arrested at $G_{0} / G_{1}$ phase by serum deprivation, HBP, GBP, and pancratistatin inhibited the progression of 3 Y1 fibroblasts from $\mathbf{G}_{0} /$ $G_{1}$ to $S$ phase. In addition, when the effect on cell cycle progression was studied in $3 Y 1$ fibroblasts synchronized at late $G_{1}$ /early $S$ phases by treating with hydroxyurea, HBP blocked further progression through $S$ phase, while GBP and pancratistatin did not affect the progression, but retarded it. On the other hand, when the effect of HBP and GBP on the progression was evaluated in promyelocytic leukemia HL-60RG cells synchronized at $G_{0} /$ $G_{1}$ phase, the cells did not progress into $S$ phase and accumulated in sub $G_{0} / G_{1}$ phase, which indicated apoptotic cells. These findings suggest that of Amaryllidaceae alkaloids, HBP blocks the progression of cell cycle at least at $G_{0} / G_{1}$ and $S$ phases and $G B P$ does at least at $G_{0} / G_{1}$ phase, resulting in apoptosis induction in tumor cells.
\end{abstract}

Key words Amaryllidaceae alkaloid; cell cycle; cytotoxicity; $\mathrm{G}_{0} / \mathrm{G}_{1}$ arrest; 1 - $O$-(3-hydroxybutyryl)pancratistatin; $1-O-(3-O-\beta$ D-glucopyranosylhybutyryl)pancratistatin

Amaryllidaceae is well known for its alkaloid constituents, which show various biological activities, such as antiviral, ${ }^{1,2}$ ) antimalarial, ${ }^{3)}$ antineoplastic, ${ }^{4-6)}$ and cytotoxic, ${ }^{7,8)}$ and antidementia $^{9,10)}$ activities. Among the family, Zephyranthes carinata has been used as a hair-growing agent in Mexico. Some Zephyranthes genus plants are also used for treatment of primary cancer, diabetes, and infection with virus. ${ }^{1,2,11)}$ In our previous study, we isolated pancratistatin and its derivatives, $1-O$-(3-hydroxybutyryl)pancratistatin (HBP), and $1-O-(3-O-\beta$ D-glucopyranosylbutyryl)pancratistatin (GBP), from Zephyranthes carinata. Pancratistatin is already known to exhibit a highly characteristic differential cytotoxicity profile against the U. S. National Cancer Institute's (NCI) panel and is the Amaryllidaceae alkaloid with the most potent cytotoxicity. ${ }^{12-15)}$ However, HBP was found to show a stronger cytotoxic activity than pancratistatin against $\mathrm{HeLa}, \mathrm{KB}$, and P388-D1, while GBP showed similar activity with pancratistatin. ${ }^{16,17)}$ Many alkaloids with cytotoxicity have been isolated from Amaryllidaceae to date, whereas the mechanism underlying their cytotoxicity has hardly been studied.

In the present study, we therefore investigated the mechanism by which HBP or GBP in addition to pancratistatin inhibits proliferation of rat embryo fibroblasts $3 \mathrm{Y} 1$ and human promyelocytic leukemia HL-60 RG cells.

\section{MATERIALS AND METHODS}

Materials Fetal calf serum (FCS), Dulbecco's Modified Essential Medium (DMEM) (with non-essential amino acids) and RPMI-1640 were obtained from Irvine Scientific Co. (Santa Ana, CA, U.S.A.). Antibiotics (penicillin and streptomycin) were from Life Technologies Inc. (Grand Island N.Y., U.S.A.). Trypsin (pancreas protease) was from Merck Co. (Frankfurt, Germany). Proteinase K, RNase A, and 3'-(4,5-dimethylthiazol-2-yl)-2,5-diphenyl-tetrazolium bromide (MTT) were obtained from Sigma Chemical Co. (St. Louis, MO, U.S.A.). HBP, GBP, and pancratistatin were isolated from the bulbs of Zephyranthes carinnta in our laboratory. ${ }^{16)}$

Cell Culture and Synchronization 3Y1 (rat embryo fibroblasts) and HL-60RG (human promyelocytic leukemia) were provided by the Health Science Research Resources Bank (Sennan, Osaka, Japan). 3Y1 and HL-60RG cells were cultured in DMEM and RPMI-1640 medium supplemented with $10 \%$ heat-inactivated FCS, $50 \mathrm{U} / \mathrm{ml}$ penicillin and 50 $\mu \mathrm{g} / \mathrm{ml}$ streptomycin at $37^{\circ} \mathrm{C}$ in a humidified atmosphere of $5 \% \mathrm{CO}_{2}$ in air, respectively. For cell synchronization at $\mathrm{G}_{0} / \mathrm{G}_{1}$ phase, 3 Y $1\left(3 \times 10^{5}\right)$ and HL-60RG cells $\left(2 \times 10^{6}\right)$ were cultured in the medium supplemented by $0.5 \%$ of FCS for $36 \mathrm{~h}$ and RPMI1640 without FCS for $48 \mathrm{~h}$, respectively. To examine the effect of chemicals, cultures were growth arrested as described above, followed by incubation in medium supplemented with $10 \%$ FCS containing HBP, GBP, and pancratistatin at a concentration of $2.5 \mu \mathrm{M}$. At the indicated time points after release, cells were harvested and their progress in cell cycle was determined by flowcytometry (FACScan, Becton Dickinson, Franklin Lakes, NJ, U.S.A.). For cell synchronization at late $\mathrm{G}_{1}$ /early S-phase, $3 \mathrm{Y} 1$ cells $\left(3 \times 10^{5}\right)$ were growth arrested by serum deprivation (DMEM with $0.5 \%$ FCS) for $48 \mathrm{~h}$, followed by incubation in medium supplemented with $10 \%$ FCS for $10 \mathrm{~h}$. The cells were treated with $10 \mathrm{~mm}$ hydroxyurea for another $14 \mathrm{~h}$. For relieving cells from late $\mathrm{G}_{1}$ /early $\mathrm{S}$-phase, the cells were washed with phosphate buffered saline (PBS) and cultured in the medium supplemented with $10 \%$ FCS containing HBP, GBP, and pancratistatin in a concentration of $2.5 \mu \mathrm{M}$. At the indicated time points after release, cells were harvested and their progress in cell cycle was determined by flowcytometry.

Flow Cytometric Analysis 3Y1 and HL-60RG cells exposed to HBP, GBP, and pancratistatin for the indicated time were harvested by centrifugation and washed with PBS. The cells were fixed with ice-cold $70 \%$ methanol for $30 \mathrm{~min}$, washed with PBS, and then treated with $1 \mathrm{ml}$ of $1 \mathrm{mg} / \mathrm{ml}$ RNase A solution (containing $0.112 \mathrm{mg} / \mathrm{ml}$ trisodium citrate) at $37^{\circ} \mathrm{C}$ for $30 \mathrm{~min}$. Cells were harvested by centrifugation at 
$400 \times \boldsymbol{g}$ for $5 \mathrm{~min}$ and stained with $250 \mu \mathrm{l}$ of nuclear staining solution $(10 \mathrm{mg}$ propidium iodide, $0.1 \mathrm{mg}$ trisodium citrate, and $0.03 \mathrm{ml}$ Triton X-100 were dissolved in $100 \mathrm{ml} \mathrm{H}_{2} \mathrm{O}$ ) at room temperature for $30 \mathrm{~min}$ in the dark. After adding $750 \mu \mathrm{l}$ PBS, the DNA content in each cell cycle phase was determined by FACScan (Beckton Dickinson).

Cytotoxic Assay One tenth milliliter of cell suspension of $3 \mathrm{Y} 1$ cells $\left(5 \times 10^{4}\right.$ cells $\left./ \mathrm{ml}\right)$ was seeded into a 96-multiwell plate and cultured for $24 \mathrm{~h}$. After washing the cells with PBS, $0.1 \mathrm{ml}$ of medium containing various concentrations of HBP, GBP, pancratistatin, methotrexate, and vinblastine were added into the cultures, followed by incubation in a humidified atmosphere of $5 \% \mathrm{CO}_{2}$ in air for the indicated time. The cytotoxic activity was determined by measuring the surviving cell number using the MTT method. ${ }^{18)}$

Analysis of DNA Fragmentation by Agarose Gel Electrophoresis HL-60RG cells $\left(2 \times 10^{6}\right.$ cells $\left./ 10 \mathrm{ml} / \mathrm{dish}\right)$ exposed to $2.5 \mu \mathrm{M}$ HBP, GBP, and pancratistatin for 3,6 , and $9 \mathrm{~h}$ were collected in a tube and then washed with PBS. The cells were incubated for $10 \mathrm{~min}$ in $500 \mu \mathrm{l}$ of lysis buffer (20 mm Tris- $\mathrm{HCl} \mathrm{pH} 7.4,10 \mathrm{~mm}$ EDTA, 0.2\% Triton X-100) at room temperature and centrifuged at $10000 \times \boldsymbol{g}$ for $10 \mathrm{~min}$ at $4{ }^{\circ} \mathrm{C}$. The supernatant was incubated overnight at $50{ }^{\circ} \mathrm{C}$ with $100 \mu \mathrm{g} / \mathrm{ml}$ proteinase K. DNA was extracted with 1 vol. of chloroform/phenol $(1: 1)$, precipitated from the aqueous phase with 1 vol. of isopropanol and $500 \mathrm{~mm} \mathrm{NaCl}$ at $-20^{\circ} \mathrm{C}$ overnight and collected by centrifugation at $14000 \times \boldsymbol{g}$ for $30 \mathrm{~min}$ at $0^{\circ} \mathrm{C}$. The pellet was suspended in $70 \%$ ethanol, centrifuged at $14000 \times \boldsymbol{g}$ for $10 \mathrm{~min}$ at $0{ }^{\circ} \mathrm{C}$, then dried under reduced pressure and incubated in $25 \mu \mathrm{l}$ of $10 \mathrm{~mm}$ Tris- $\mathrm{HCl}$, pH 7.5 and $1 \mathrm{~mm}$ EDTA for $1 \mathrm{~h}$ at $37^{\circ} \mathrm{C}$ with $1 \mu \mathrm{g} / \mathrm{ml}$ RNase A. Samples were heated at $65^{\circ} \mathrm{C}$ for $10 \mathrm{~min}$ and applied to agarose gel electrophoresis after addition of loading buffer. Horizontal electrophoresis was performed for $1 \mathrm{~h}$ at $80 \mathrm{~V}$ in $1.5 \%$ agarose gel with Tris-borate/EDTA electrophoresis buffer $(\times 0.5)$. After treatment of gel with $0.5 \mu \mathrm{g} / \mathrm{ml}$ of ethidium bromide for $10 \mathrm{~min}$, DNA was visualized by UV illumination.

\section{RESULTS}

To evaluate the cytostatic activity of HBP and GBP which are derivatives of pancratistatin, we first studied the effect of both alkaloids on rat embryo fibroblasts 3 Y 1 . 3Y $1\left(5 \times 10^{4} /\right.$ $\mathrm{ml}$ ) were incubated with HBP and GBP for $48 \mathrm{~h}$ at varying concentrations and thereafter the viability of cells was determined according to the MTT method. As shown in Fig. 1A, HBP inhibited cell proliferation at an $\mathrm{IC}_{50}$ smaller than that of pancratistatin, while GBP showed a cytostatic activity similar to that of pancratistatin. When the time course of cell death was examined at a concentration of $2.5 \mu \mathrm{M}, \mathrm{HBP}$ and GBP completely inhibited the proliferation, but they did not show significant cytotoxicity until $48 \mathrm{~h}$ (Fig. 1B).

Therefore, the effect of HBP and GBP on the progression of cell cycle was evaluated using $3 \mathrm{Y} 1$ fibroblasts synchronized at $\mathrm{G}_{0} / \mathrm{G}_{1}$ phase by serum deprivation (DMEM with $0.5 \% \mathrm{FCS}$ ) for $36 \mathrm{~h}$ as described in the legend of Fig. 2. In control fibroblasts, the addition of the medium containing $10 \%$ FCS led the cells to $\mathrm{S}$ phase from $12 \mathrm{~h}$ after the addition. At $21 \mathrm{~h}$ after the addition of serum, the cells began to accumulate at $G_{1}$ phase again. In contrast, the addition of
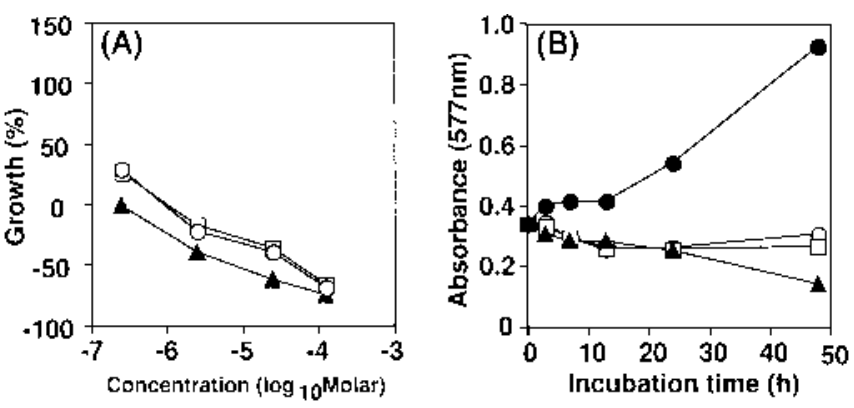

Fig. 1. Inhibitory Activity of Amaryllidaceae Alkaloids against Proliferation of $3 \mathrm{Y} 1$ Fibroblasts

(A) 3 Y1 fibroblasts $\left(5 \times 10^{4} / \mathrm{ml}\right)$ were incubated for $48 \mathrm{~h}$ in the presence of $\mathrm{HBP}(\boldsymbol{\Delta})$, GBP $(\square)$, and pancratistatin $(\bigcirc)$ at the concentrations indicated in the figure. (B) 3 Y 1 fibroblasts $\left(5 \times 10^{4} / \mathrm{ml}\right)$ were incubated with $2.5 \mu \mathrm{M}$ of HBP $(\mathbf{\Delta})$, GBP $(\square)$, pancratistatin $(\bigcirc)$, and nothing $(\bigcirc)$ for the indicated time. Cell viability was determined by the MTT method.

HBP, GBP, and pancratistatin completely abolished the release from $\mathrm{G}_{0} / \mathrm{G}_{1}$ (Fig. 2).

We then examined the effect on 3Y1 fibroblasts, which were synchronized at late $\mathrm{G}_{1}$ /early $\mathrm{S}$ phases by treating cells with $10 \mathrm{~mm}$ of hydroxyurea for $14 \mathrm{~h}$. The detailed procedure is described in the legend of Fig. 3. In control cells, most cells entered into $G_{2} / M$ phase $6 \mathrm{~h}$ after hydroxyurea removal and returned to $G_{0} / G_{1}$ phase by $12 \mathrm{~h}$. On the other hand, HBP-treated cells were arrested at late $G_{1}$ /early $S$ phases until $12 \mathrm{~h}$ after hydroxyurea removal, indicating that HBP appeared to inhibit DNA synthesis. GBP and pancratistatin treatment did not prevent the shift from late $\mathrm{G}_{1}$ /early $\mathrm{S}$ to $\mathrm{G}_{2} / \mathrm{M}$ phase, but the progress was slower than control cells. The Amaryllidaceae alkaloid vinblastine is well known to bind to tubulin and inhibit microtubule assembly, resulting in cell arrest at $\mathrm{M}$ phase. ${ }^{19)}$ In fact, although data is not shown, vinblastine forced cells to accumulate at $G_{2} / M$ phase in this protocol.

We have already shown that HBP and GBP were cytotoxic against various kinds of tumor cells. ${ }^{16,17)}$ In the present study, we found that the cell death which HBP and GBP induced in HL-60RG cells was apoptosis, evidenced by the fact that they caused the cleavage of chromosomal DNA in HL-60RG cells (Fig. 4), which is regarded as a biochemical marker of apoptosis.

We then examined the effects of HBP and GBP on the progression of cell cycle using HL-60RG cells synchronized at $\mathrm{G}_{0} / \mathrm{G}_{1}$ phase by serum deprivation. As $3 \mathrm{Y} 1$ fibroblasts, HL$60 R G$ cells stayed at $G_{0} / G_{1}$ phase until $9 \mathrm{~h}$ and then entered into $\mathrm{S}$ phase from $12 \mathrm{~h}$ after the addition of FCS. As shown in Fig. 5, HBP or GBP treatment did not affect the distribution of cell cycle phases significantly, whereas the cells in sub $\mathrm{G}_{0} / \mathrm{G}_{1}$ phase, which indicated dead cells, increased with time, thus indicating that HBP and GBP induced cell death in the tumor cells arrested at $\mathrm{G}_{0} / \mathrm{G}_{1}$ phase.

\section{DISCUSSION}

We have studied the cytotoxicity shown by Amaryllidaceae alkaloids to date and clarified that two derivatives of pancratistatin, HBP and GBP, showed potent cytotoxicity against various tumor cells. ${ }^{16,17)}$ In the present study, to address the mechanism underlying the cytotoxicity of Amaryll- 


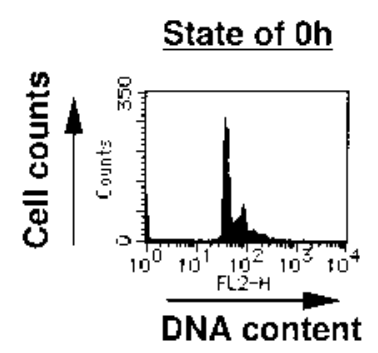

$\underline{\text { 12h }}$

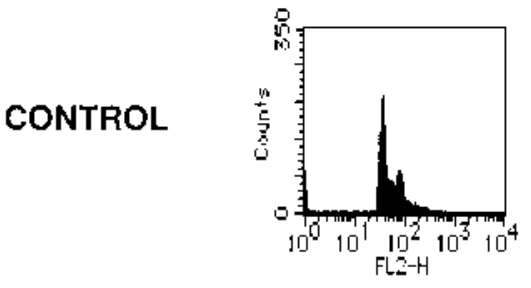

HBP
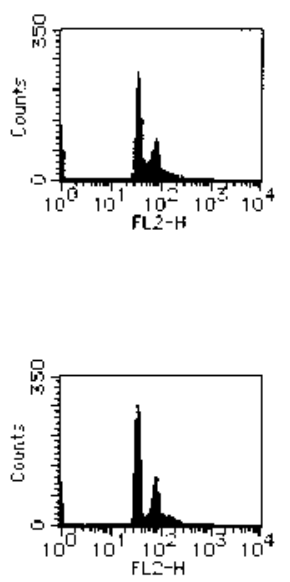

GBP

\section{Pancratistatin}

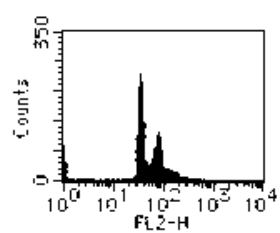

$\underline{15 h}$
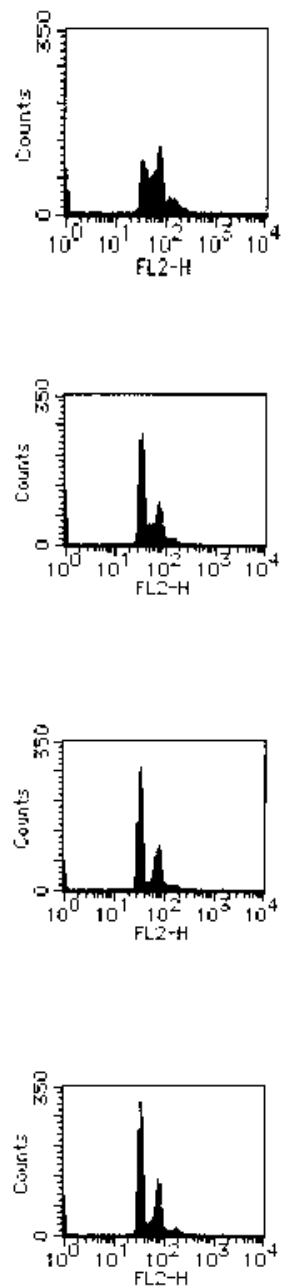

$\underline{181}$
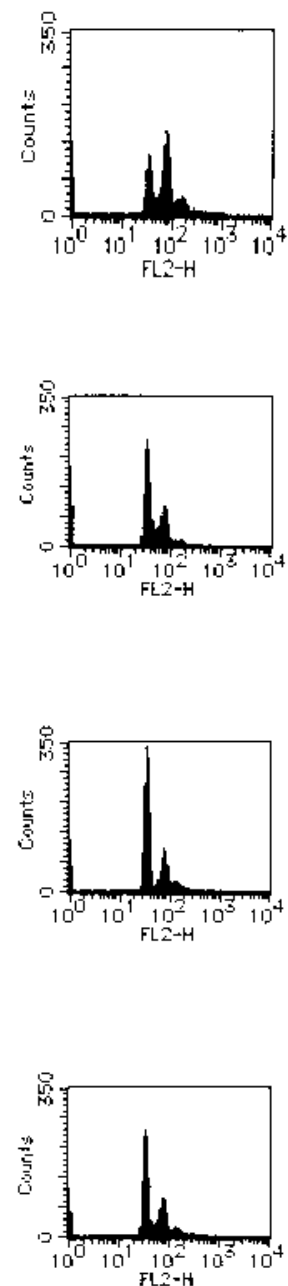

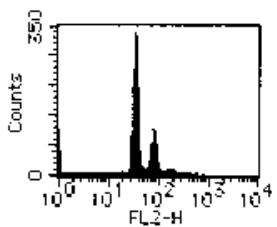

$\underline{21 h}$
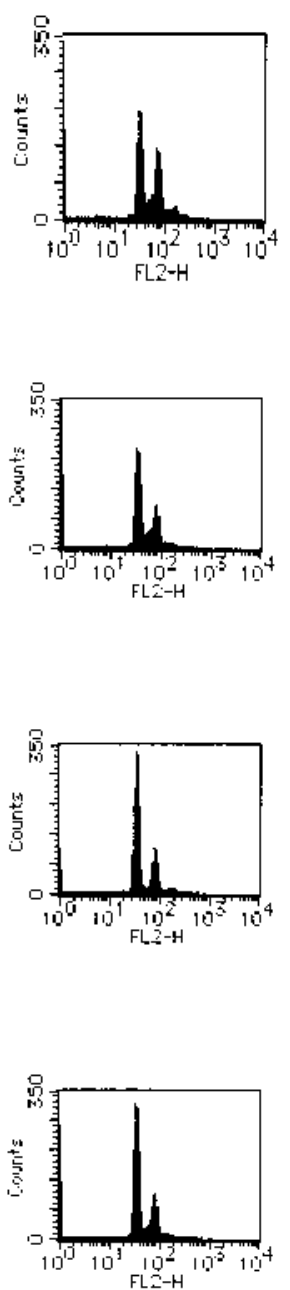

Fig. 2. Effect of Amaryllidaceae Alkaloids on the Progression of Cell Cycle in 3 Y1 Fibroblasts Synchronized at $\mathrm{G}_{0} / \mathrm{G}_{1}$ Phase by Serum Deprivation

$3 \mathrm{Y} 1$ fibroblasts were plated at a concentration of $3 \times 10^{5} / \mathrm{ml}$ and maintained in DMEM containing $0.5 \%$ fetal bovine serum (FBS) for $36 \mathrm{~h}$ to arrest the cells at $\mathrm{G}_{0} / \mathrm{G}_{1}$ phase. Following the incubation, $3 \mathrm{Y} 1$ fibroblasts were incubated in the medium supplemented with $10 \% \mathrm{FCS}$ containing HBP, GBP, and pancratistatin in a final concentration of $2.5 \mu \mathrm{M}$. Then, at every three hours after release from $\mathrm{G}_{0} / \mathrm{G}_{1}$ phase, the progression of cell cycle was determined by flowcytometry after staining the cells with propidium iodide. Data at 0 , $12,15,18$, and $21 \mathrm{~h}$ are represented in this figure.

idaceae alkaloids, we examined the regulatory action of the alkaloids on the cell cycle. For this purpose, we used rat embryo fibroblasts $3 \mathrm{Y} 1$, which are widely used in the study of cell cycle and cell synchronization, because HBP and GBP showed only a mild cytotoxicity against $3 Y 1$ cells, when compared with other tumor cells.

Many methods have been reported to study the cell cycle to date. Among them, serum deprivation and hydroxyurea were selected to synchronize cells at $G_{0} / G_{1}$ and late $G_{1}$ /early $\mathrm{S}$ phases, respectively. Serum deprivation is a commonly used method to synchronize cell lines at the $\mathrm{G}_{0}$ phase of the cell cycle. Hydroxyurea, which inhibits ribonucleotide reductase activity, ${ }^{20)}$ can cause a reversible late $\mathrm{G}_{1}$ /early S-phase arrest.

According to both methods, HGB was found to block the release from $\mathrm{G}_{0} / \mathrm{G}_{1}$ phase and inhibit the progression through $\mathrm{S}$ phase. In the serum deprivation experiment, when HBP was added at late $\mathrm{S} / \mathrm{G}_{2}$ phase, HBP did not suppress the progression, suggesting that HBP does not influence $\mathrm{G}_{2} / \mathrm{M}$ phase (data was not shown). However, as alkaloids like vinblastine 


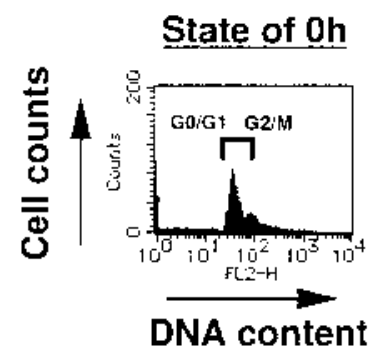

6h

\section{CONTROL}

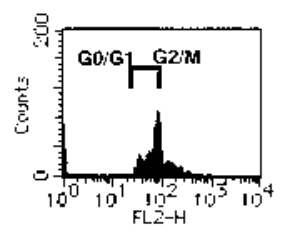

HBP
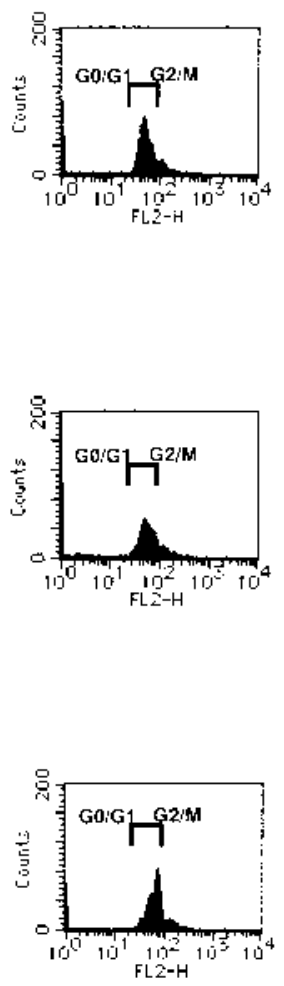

9h
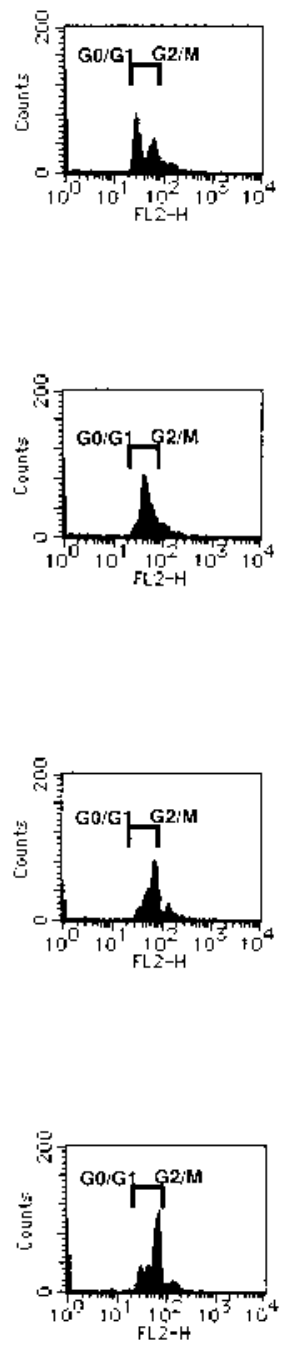

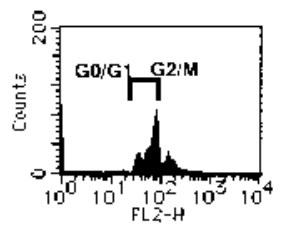

$12 h$
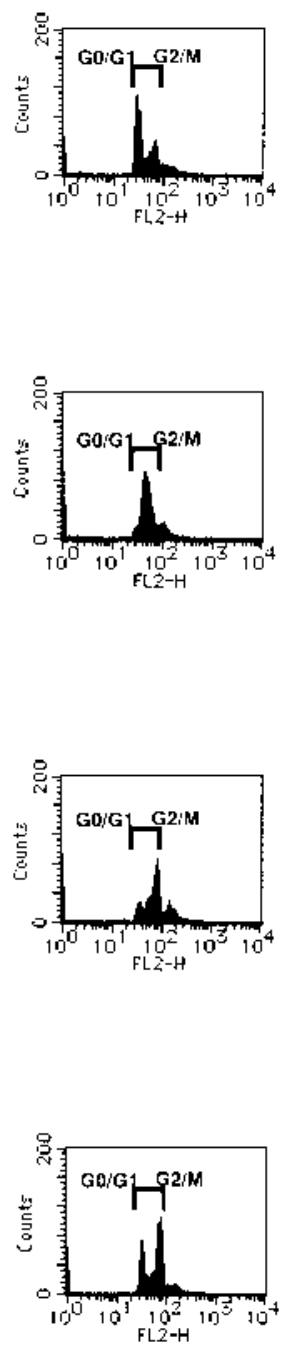

Fig. 3. Effect of Amaryllidaceae Alkaloids on the Progression of Cell Cycle in 3Y1 Fibroblasts Synchronized at Late $\mathrm{G}_{1} /$ Early S Phase by Treating with Hydroxyurea

3 Y 1 fibroblasts were plated at a concentration of $3 \times 10^{5} / \mathrm{ml}$, incubated in DMEM containing $0.5 \%$ FCS for $36 \mathrm{~h}$, and then incubated in DMEM supplemented with $10 \%$ FCS for $10 \mathrm{~h}$. Then the cells were treated with $10 \mathrm{~mm}$ hydroxyurea for $14 \mathrm{~h}$, followed by addition of HBP, GBP, and pancratistatin at a concentration of $2.5 \mu \mathrm{m}$. The progression of cell cycle was determined by flowcytometry at 6,9 , and $12 \mathrm{~h}$ after the addition of alkaloids.

and vincristine arrested cells at $\mathrm{M}$ phase by inhibiting microtuble assembly, ${ }^{19)}$ further study of HBP is required to elucidate the mechanism. On the other hand, GBP was found to arrest at $\mathrm{G}_{0} / \mathrm{G}_{1}$, but not $\mathrm{S}$ and $\mathrm{G}_{2} / \mathrm{M}$ phases. HBP is devoid of a glucose residue on the hydroxybutyryl group of GBP and appears to differ from GBP in solubility in water or permeability of membrane. This indicates that HBP should be able to access the machinery of the cell cycle more easily than
GBP, resulting in extensive inhibition of cell proliferation.

In the study using tumor cells HL-60RG, HBP and GBP suppressed the progression into $\mathrm{S}$ phase, as evidenced in $3 \mathrm{Y} 1$ fibroblasts. In addition, both alkaloids increased sub $G_{0} / G_{1}$ population, indicating that they induced apoptosis. The reason why the arrest at $\mathrm{G}_{0} / \mathrm{G}_{1}$ phase for long time induces apoptosis in tumor cells is not clear.

Recently, agents causing cell cycle-mediated apoptosis are 
being increasingly appreciated to be ideal for the management of cancer. From this point of view, synthetic inhibitors of cyclin dependent kinases (CDKIs) are typical representatives of such drugs. Olomoucine, flavopiridol, butyrolactone I and their derivatives selectively inhibit CDKs and thus constrain tumor cell proliferation, finally resulting in apoptosis induction. ${ }^{21)}$

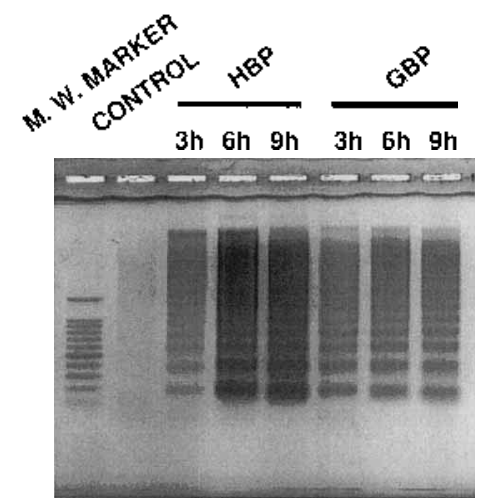

Fig. 4. Agarose Gel Electrophoresis of DNA Extracted from HL-60RG Cells Treated with HBP and GBP

HL-60RG cells $\left(2 \times 10^{5}\right.$ cells $\left./ \mathrm{ml}\right)$ exposed to $2.5 \mu \mathrm{M}$ HBP and GBP for 3,6 , and $9 \mathrm{~h}$ were harvested, followed by DNA extraction according to the method described in Materials and Methods. The DNA extracted was subjected to electrophoresis on $1.5 \%$ agarose gel. Lane 1, 100 b.p. ladder marker; lane 2, control; lane 3-5, HBP; lane $6-8$, GBP.
There are also some reports concerning the efficacy of cell cycle inhibitors in rheumatoid arthritis. CDKI is effective to suppress collagen-induced arthritis in mice by inhibiting synovial cell proliferation. ${ }^{22,23)}$ Paclitaxel, which is a unique antineoplastic agent and induces arrest of the cell cycle at $\mathrm{G}_{2} / \mathrm{M}$ phase and apoptosis, is also known to suppress collagen-induced arthritis. ${ }^{24)}$ In addition, inhibition of the cell cycle is also reported to be useful for the prevention of atherosclerosis. PCA-4230, which blocks cyclin D1 and cyclin A expression and abrogates hyperphosphorylation of the retinoblastoma gene product, suppressed the growth of human vascular smooth muscle cells in vitro. ${ }^{25)}$ Gene therapy strategies targeting CDK2 and E2F function and Rb hyperphosphorylation have proven efficient at preventing vascular proliferative diseases in animal models ${ }^{26,27)}$ and human bypass-graft atherosclerosis. ${ }^{28)}$ Thus, accumulating evidence suggests that the regulation of the cell cycle of the pathogenetic cells implicated in various chronic diseases is able to stop or improve the development of diseases. Therefore, the agents that can modulate cell progression or arrest cells at a specific cell cycle phase should provide a useful novel therapy for cell proliferating diseases. Our finding in this study that HBP and GBP inhibit the progression through specific cell cycle phases may provide a potential therapy for cancer, rheumatoid arthritis, atherosclerosis and so on. $\underline{\text { Oh }}$

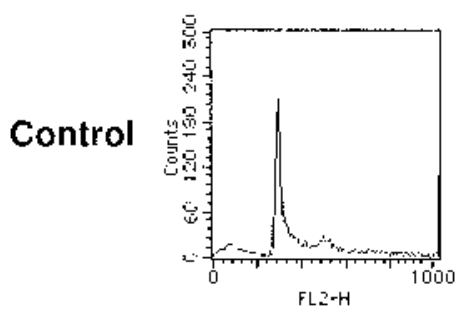

GBP

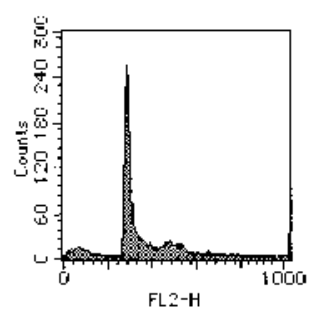

HBP $\underline{3 h}$
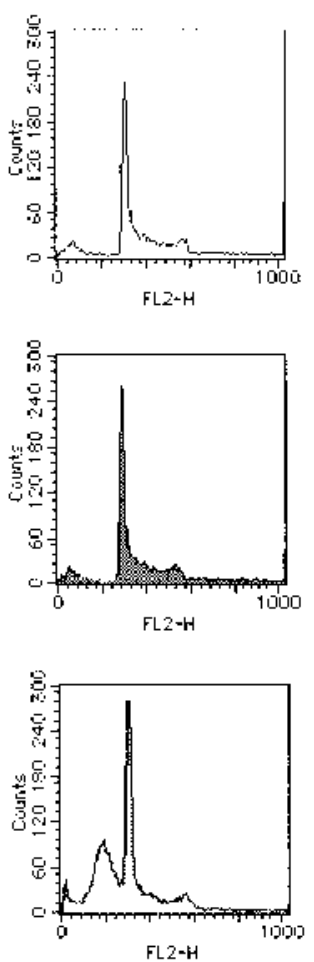

$\underline{6 h}$
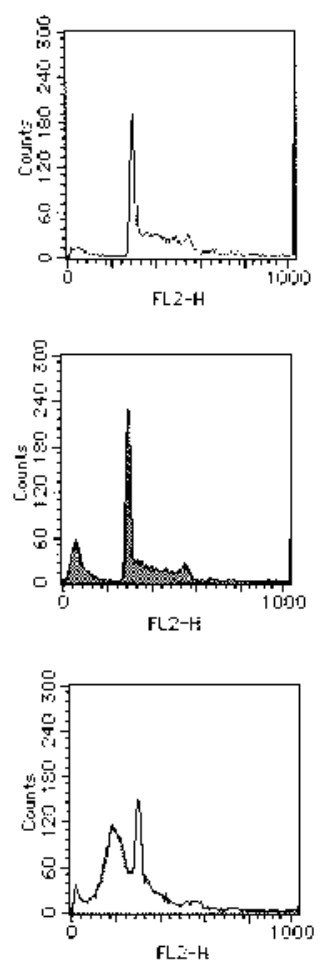

9h
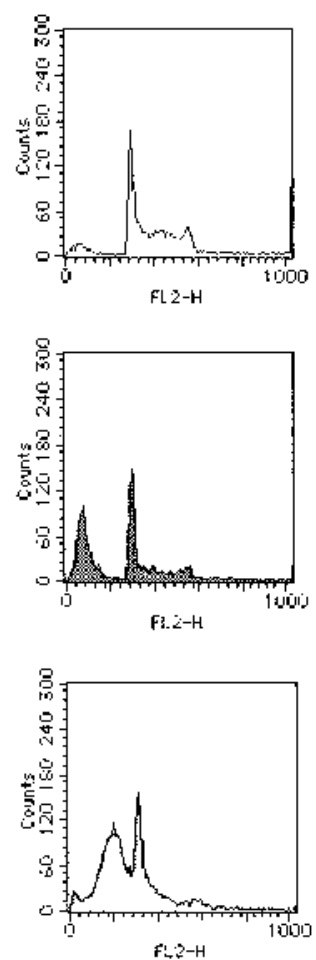

Fig. 5. Effect of HBP and GBP on the Progression of Cell Cycle in HL-60RG Cells Synchronized at $\mathrm{G}_{0} / \mathrm{G}_{1}$ Phase by Serum Deprivation

HL-60RG cells were plated at a concentration of $2 \times 10^{6} / \mathrm{ml}$ and maintained in RPMI1640 without FCS for $48 \mathrm{~h}$ to arrest the cells at $\mathrm{G}_{0} / \mathrm{G}_{1}$ phase. Following the incubation, HL$60 \mathrm{RG}$ cells were incubated in the medium supplemented with $10 \%$ FCS containing HBP and GBP in a final concentration of $2.5 \mu \mathrm{m}$. Then, at every three hours after release from $\mathrm{G}_{0} / \mathrm{G}_{1}$ phase, the progression of cell cycle was determined by flowcytometry after staining the cells with propidium iodide. Data at $0,3,6$, and $9 \mathrm{~h}$ are represented in this figure. 


\section{REFERENCES}

1) Gabrielsen B., Monath T. P., Huggins J. W., Kefauver D. F., Pettit G. R., Groszek G., Hollingshead M., Kirsi J. J., Shannon W. M., Schubert E. M., Dare J., Ugarkar B., Ussery M. A., Phelan M. J., J. Nat. Prod., 55, 1569-1581 (1992).

2) Van den Berghe D. A., Vlietinck A. J., Van Hoof L., Bull. Inst. Pasteur., 84, 101-105 (1986).

3) Likhitwitayawuid K., Angerhofer C. K., Chai H., Pezzuto J. M., Cordell G. A., J. Nat. Prod., 56, 1331-1338 (1993).

4) Pettit G. R., Gaddamidi V., Goswami A., Cragg G. M., J. Nat. Prod., 47, 796-801 (1984).

5) Furusawa E., Irie H., Combs D., Wildman W. C., Chemother., 26, 3645 (1980).

6) Furusawa E., Furusawa S., Oncology, 45, 180-186 (1988).

7) Weniger B., Italiano L., Beck J. P., Bastida J., Bergonon S., Codina C., Lobstein A., Anton R., Planta Med., 61, 77-79 (1995).

8) Antoun M. D., Mendoza N. T., Rios Y. R., Proctor G. R., Wickramaratne D. B. M., Pezzuto J. M., Kinghorn A. D., J. Nat. Prod., 56, $1426-1425$ (1993).

9) Thomsen T., Bickel U., Fischer J. P., Kewitz H., Eur. J. Clin. Pharmacol., 39, 603-605 (1990).

10) Bores G. M., Huger F. P., Petko W., Mutlib A. E., Camacho F., Rush D. K., Selk D. E., Wolf V., Kosley R. W., Jr., Davis L., Vargas H. M., J. Pharmacol. Exp. Ther., 277, 728-738 (1996).

11) Pettit G. R., Gaddamidi V., Cragg G. M., J. Nat. Prod., 47, $1018-$ 1020 (1984)

12) Pettit G. R., Cragg G. M., Singh S. B., Duke J. A., Doubek D. L., J. Nat. Prod., 53, 176-178 (1990).

13) Pettit G. R., Gaddamidi V., Herald D. L., Singh S. B., Cragg G. M.,
Schmidt J. M., Boettner F. E., Williams M., Sagawa Y., J. Nat. Prod., 49, 995-1002 (1986).

14) Pettit G. R., Pettit G. R., 3rd, Backhaus R. A., Boyd M. R., Meerow A. W., J. Nat. Prod., 56, 1682-1687 (1993).

15) Pettit G. R., Pettit G. R., 3rd, Groszek G., Backhaus R. A., Doubek D. L., Barr R. J., Meerow A. W., J. Nat. Prod., 58, 756-759 (1995).

16) Kojima K., Mutsuga M., Inoue M., Ogihara Y., Phytochemistry, 48, 1199-1202 (1998)

17) Mutsuga M., Kojima K., Nose M., Inoue M., Ogihara Y., Natural Med., 55, 201-204 (2001).

18) Mosmann T., J. Immunol. Methods, 65, 55-63 (1983).

19) Jordan M. A., Thrower D., Wilson L., Cancer Res., 51, 2212-2222 (1991).

20) Timson J., Mutat. Res., 32, 115-132 (1975).

21) Hajduch M., Havlieek L., Vesely J., Novotny R., Mihal V., Strnad M., Adv. Exp. Med. Biol., 457, 341-353 (1999).

22) Nasu K., Kohsaka H., Nonomura Y., Terada Y., Ito H., Hirokawa K., Miyasaka N., J. Imunol., 166, 7246-7252 (2001).

23) Taniguchi K., Kohsaka H., Inoue N., Terada Y., Ito H., Hirokawa K., Miyasaka N., Nat. Med., 5, 760-767 (1999).

24) Kurose A., Yoshida W., Yoshida M., Sawai T., Cytometry, 44, 349 354 (2001).

25) Goukassian D., Sanz-González S. M., Pérez-Roger I., Font de Mora J., Ureña J., Andrés V., Br. J. Pharmacol., 132, 1597-1605 (2001).

26) Andrés V., Int. J. Molec. Med., 2, 81-89 (1998).

27) Braun-Dullaeus R. C., Mann M. J., Dzau V. J., Circulation, 98, 82-89 (1998).

28) Mann M. J., Whittemore A. D., Donaldson M. C., Belkin M., Conte M. S., Polak J. F., Orav E. J., Ehsan A., Dell'acqua G., Dzau V. J., Lancet, 354, 1493-1498 (1999). 